The Open Construction \& Building
Bentham OPen
TrossMark
Technology Journal
Content list available at: www.benthamopen.com/TOBCTJ/ $10.2174 / 1874836801711010458$

\title{
RETRACTION
}

\section{Retraction Notice: Research on Decorative Effect of Architectural Decoration Materials}

\author{
Yafeng Sun $^{*}$ \\ School of Architectural Design and Decoration in Jiangsu Jianzhu Institute, Xuzhou, 221116, Jiangsu, China
}

\section{RETRACTION}

The Publisher and Editor have retracted this article [1] in accordance with good ethical practices. After thorough investigations we believe that the peer review process was compromised. The article was published online on 09-11-2015.

\section{REFERENCE}

[1] Y. Sun, "Research on Decorative Effect of Architectural Decoration Materials", Open Constr. Build. Technol. J., vol. 9, pp. 316-320, 2015.

\section{(C) 2017 Yafeng Sun}

This is an open access article distributed under the terms of the Creative Commons Attribution 4.0 International Public License (CC-BY 4.0), a copy of which is available at: https://creativecommons.org/licenses/by/4.0/legalcode. This license permits unrestricted use, distribution, and reproduction in any medium, provided the original author and source are credited.

\footnotetext{
* Address correspondence to this author at the School of Architectural Design and Decoration in Jiangsu Jianzhu Institute, Xuzhou, 221116, Jiangsu,
} China; Tel: 13952119759; E-mail: 13952119759@139.com 